\title{
The Dynamics of Social Capital in Global Era of Rural Communities (Case Study Poor People in Nagari Rambatan, Tanah Datar District)
}

\author{
Marleni (marleni@stkip-pgri-sumbar.go.id) $)^{1}$ \\ Adiyalmon $^{2}$, Elvawati $^{3}$ \\ ${ }^{1,2,3}$ Sociology Education Department of STKIP PGRI Sumatera Barat, Indonesia
}

\begin{abstract}
This article is based on the change of social capital in society triggered by globalization. According to Soetomo (2012) social resources (social capital) is a medium that enables development to take place successfully because of cultural elements have traditional legitimacy that symbolically the most valuable communication model, and have a number of functions then make it a means for change. Based on that, the article will explore about the dynamics of social capital with a case study in Rambatan SubDistrict, Tanah Datar District, where is Nagari Rambatan as sample. Data collection using mixed methods, there are quantitative (questionnaire) and qualitative (interview). The results of research indicate the shifting of social capital in the society in Nagari Rambatan seen from the level of participation in social organization, the leaders, nagari institutions, relatives and neighbors as well as social relationships with relatives or neighbors, and also the level of dependence in economy.
\end{abstract}

Keywords: Social Capital, Rural Communities

\section{Preliminary}

Development influenced by globalization, which is not only in the urban areas but also in rural areas that affect the change of society, especially rural communities. The villagers are a strong society with values and norms. The entry of globalization of the countryside resulted in changes in values, social structure, institutions, functions, norms and all aspects related to rural society. The flow of globalization also leads to more modern villages that puncture life and society think rationally.

Globalization with its development slogan has eliminated the purpose of community development itself. The first natural resources that play an important role in community life that should be utilized for the benefit of society and community welfare but only utilized by a handful of people. Every natural resource development should take into account its conservative aspects but it is not realized. Natural resources are only depleted for development but conservatives are not implemented by those who use them. Natural resources are only made as money and capital for economic growth Both human resources, which are not seen from economic but also noneconomic role in development. Rill of human resources at the present moment in the development always thinking about the economic and production aspects so as to ignore the socio-cultural aspects so that all of natural resources are depleted to produce commodities, in addition to human resources awareness of quality is still low, especially in rural areas that have an impact on poverty. These three social resources, or so-called social capital. This resource which has been forgotten by the society when according to Soetomo in his book of community development, social resources is a media that enables development can be place successfully because the cultural element has traditional legitimation, cultural element symbolically is the most valuable communication model, the number of functions that make it a means for change. [1]

Tanah Datar District, specially in Rambatan Sub-District is also affected by globalization. This was seen from the changes that occur in the community where is the results of observation and initial interviews in the past, the community in carrying out work always work together but at the 
present where it supported by technology as a result of modernization then rural communities began to work independently. The impact is social relations in society will be more tenuous because inter-community interaction is not intensive anymore.

In addition, the impact of modernization for the poor on the positive side, they can compete globally, but in the other side in the global era of free trade is enforced so that the poor become poorer because they are not able to compete. For example the agricultural field of cheap rice prices due to the proliferation of imported rice. Home industry will die because people prefer to import goods because of good quality with low price and followed by consumptive society. Pursuant to petmasalahn above purpose of this research is to describe dynamics of social capital of global era in rural society with case study of poor society in Kecamatan Rambatan Kabupaten Tanah Datar.

\section{Literature review}

Social capital itself refers to the values and norms that are believed and carried out by most members of society in daily life that directly or indirectly affect the quality of life of individuals and the sustainability of community communities [2]. According to Bardhan in Putnam 1993, social capital is also understood as a series of norms, networks and organizations in which people have access to power and resources and where decision-making and policy are made [3].

The research on social capital is also done by Areekul et al, 2015 with the title of his research Development For Strengthening Capital Capital Social Capital For Being A Sustainable Lifelong Learning Society, where he sees the components of social capital comprising humans, institutions, knowledge of cultural wisdom, public funds and resources natural. The social capital strengthening component consists of five stages: credible participation in learning problems, credible participation in decision making, credible participation in implementation, credible participation in benefits, and credible participation in evaluation [4].

Social Capital also defines resources that can be cultivated as an investment to acquire new resources. Social capital places greater emphasis on the potential of groups and patterns of interpersonal relationships within a group and between groups with an attention space on social networks, norms, values and beliefs among peers born from group members and to being a group. [5] According to the World Bank (1999) defines social capital as referring to institutional dimensions, established relationships and norms that shape the quality and quantity of social relations in society. In Hasbullah (2006: 6), Cohen and Prusak (2001) provide the notion that social capital is the stock of an active relationship between communities. Each relationship pattern that occurs is bound by trust, mutual understanding, shared values that bind members of the group to make possible joint actions can be done efficiently and effectively. Social capital is also defined as a set of processes of interpersonal relationships supported by networks, norms, and social beliefs that enable efficient and effective coordination and cooperation for mutual benefit and virtue. According to Putnam social capital consists of five principal characteristics, namely:

1. Community Network voluntary number and density, country and private network.

2. Civic engagement: the participation and use of civil networks.

3. The identity of local citizenship: a sense of belonging, of solidarity and equality with other members of the Community.

4. Reciprocal and cooperative norms: a sense of duty to help others, along with confidence that the aid will be restored.

5. Trust in the community.

\section{Method}


This research uses qualitative and quantitative approaches, with data collection techniques (writings), observation or observation, in-depth interviews and questionnaires. Data analysis is done by quantitative approach (descriptive and inferential numerical analysis) and qualitative (descriptive and analytical texts or images systematically) or between these two approaches. The initial strategy is to collect certain stages or themes of participation (qualitative stage) and then use the stages as specific items and themes as scales to create quantitative survey instruments. In the third stage validate the instrument with a representative sample of the population.

\section{Finding and Discussion}

\section{Social Capital Dynamics in Global Era of Rural Communities}

Development is influenced by globalization, not only in the urban areas but also in rural areas that affect the change of society, especially rural communities. The is a strong society with values and norms. The entry of globalization in the rural resulted some changes in values, social structures, institutions, functions, norms and all aspects related to rural society. The flow of globalization also leads to more modern villages that puncture life and society think rationally.

People's thinking rationally affects social capital, where there is dynamics or changes in social capital in the poor in Rambatan Sub-District. Social change is changes in the social institutions that affect their social systems, including social values systems, attitudes and patterns of behaviour between groups of people [6]. Non-social determinants of social change such as climate, availability of resources and biological forces. While external factors refer to the influence that comes from the presence of other communities in intercultural environment. Internal factors refer to the linkage of values, social structures and classes as instituted in a given society [7]. The change of social capital is seen from the level of participation in social organization, and also to leaders, nagari institutions, families and neighbours and social relationships with family, neighbours, and economic dependency.

\subsection{Change of Participation in Organization}

Participation is the participation of the community in various activities that aim to overcome problems and produce something useful. While the organization is a container used by the community to achieve these goals. The globalization affecting the village community, especially Rambatan's nagging also affects the involvement and participation of the community within the organization. This can be seen from the low level of participation of the poor compared to five years ago in social organizations such as farmer groups, religious and cooperative.

On the other hand this is triggered by the development of nagari and the level of community needs is increasing, so the poor focus more on the job and the fulfillment of daily needs. Shifting values and norms due to modernization and globalization also make people more focused on personal affairs than the organization. So far, the organization used as a place of friendship by the community, but now the organization used as a place to gain profit so that people always think about profit or loss when following it. This factor makes the participation of the poor increasingly decreasing in following the organization's activities in this warehouse.

It is also disclosed by RM, the cause of the participation or inactivity of the poor in social organizations that exist in this kenagarian caused by the way of thinking society has advanced, where they think rationally and take profit or loss. The advantages they think are more to material gain, this is because to meet the needs of their lives are increasingly increasing while the conditions of land and their income is not fixed 
4.2. Trust Against Leaders, Nagari Institutions, Family and Neighbours/Friends

\section{Poor People Trust of Nagari Rambatan, Year 2017}

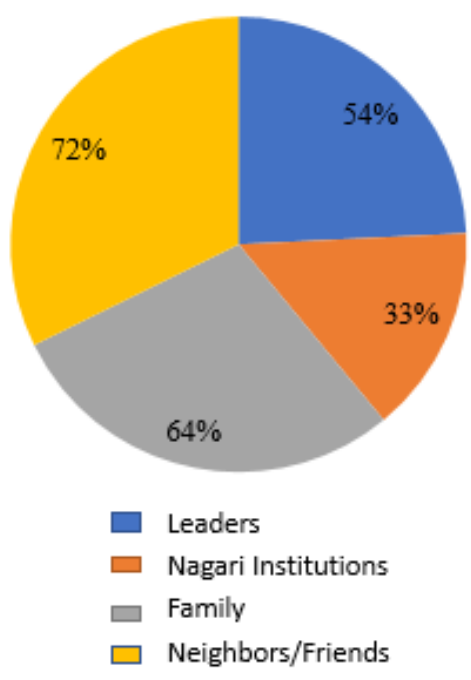

Graph 1. The Level of Trust for the Poor Country of the Year 2017

Poor People Trust of Nagari Rambatan,

Year 2012

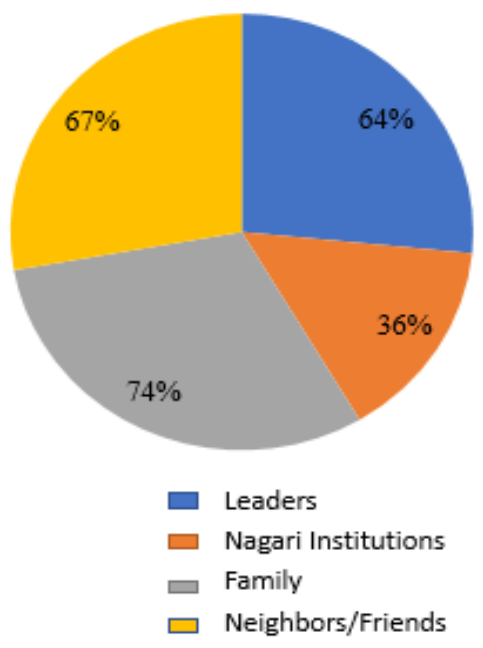


Graph 2. Level of Trust of the Poor People of the Year 2012

Based on the data above, it can be compared to changes or shifts in the level of trust of the poor to the leaders, nagari institutions, relatives or friends or neighbors. The level of confidence in the leadership experienced a $10 \%$ shift. This is caused by the meaning of the poor community leaders who only think about their own interests such as corruption without thinking about the lives of their people. Thought arises from the many corruption cases that occurred in Indonesia which involves various elements either exposed region or center. The same thing is expressed by JH, that his level of trust in the leadership is little or can be said no, because many current leaders are dishonest and understand the nature and needs of society. The position given by the community is only used as a place to find his own wealth, while the people are still many who live in poverty.

This means that ignorance of the leadership of the poor makes the level of public confidence to be reduced, the increased information and knowledge of the public will be more rational corruption cases of public thinking that affect the level of confidence in the leadership. On the other hand, globalization strengthens the level of trust of the poor towards relatives or friends / neighbors. Increased level of community trust in nagari Rambatan to friends or neighbors by $5 \%$, this is because the neighbors always provide assistance and help in economic and non economic.

In addition to the economic side, the great confidence given by the poor to friends and neighbors is the help of morale given in the form of assistance when there is a thanks giving activity or when death. For example neighbors or friends come to help in taking care of all the needs voluntarily without expecting any rewards. Therefore relationships with friends and neighbors are getting stronger even though modernization and globalization enter the lives of rural communities.

\subsection{Social Relations}

According to Durkheim, social change occurs as a result of ecological and demographic factors, which change people's lives from the traditional conditions that mechanistic solidarity binds, to the conditions of modern society bound by organizational solidarity. Increased population and increased education and community knowledge result in changes in society, especially in social relations. Based on the results of research changes in social relationships that occur in Nagari Rambatan experienced a very significant shift due to the entry of globalization that has an impact on the decline of cooperation that has formed the network within the community. This can be seen in figure 3 below.

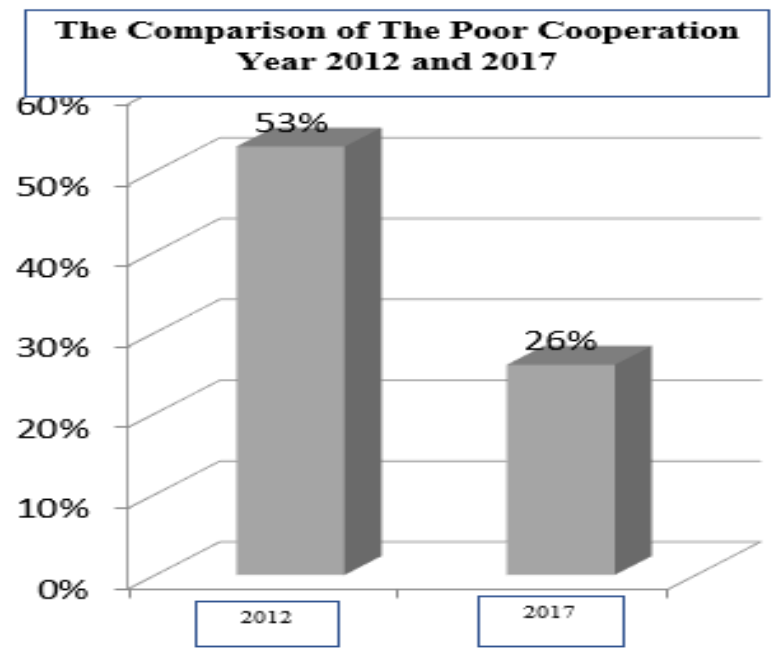


Graph 3. Comparison of Poor Cooperation in 2012 with 2017

Based on graph 3, it can be seen decreased cooperation of the poor by $27 \%$ for 5 years. This cooperation could be collective land management and other social activities. As for their reasons because the level of economic needs is increasing so that they put personal interests ahead of the public interest. In other cases, the rational mindset of society also affects the decline of cooperation among these communities. As expressed by AW; His absence in social activities such as street clean-up will not entail the performance and the completion of the road, the urgent economic interest leaves him with such activities. This means that rational thinking makes a decision more preceding economic interests because it involves family life.

Relationships with relatives also decreased by using aid and loan indicators from siblings, where the grants and liabilities imposed by respondents on relatives for 5 years decreased by $18 \%$ (see figure 4). As for their reasons that you already have their own responsibilities and are busy with activities to meet the needs of their core family. Supported also by life at the present time everything needs money so time is precious and hard to share with others. On the other hand, in terms of material economic life is almost the same while the level of demand is higher and the price purchased is also more expensive.

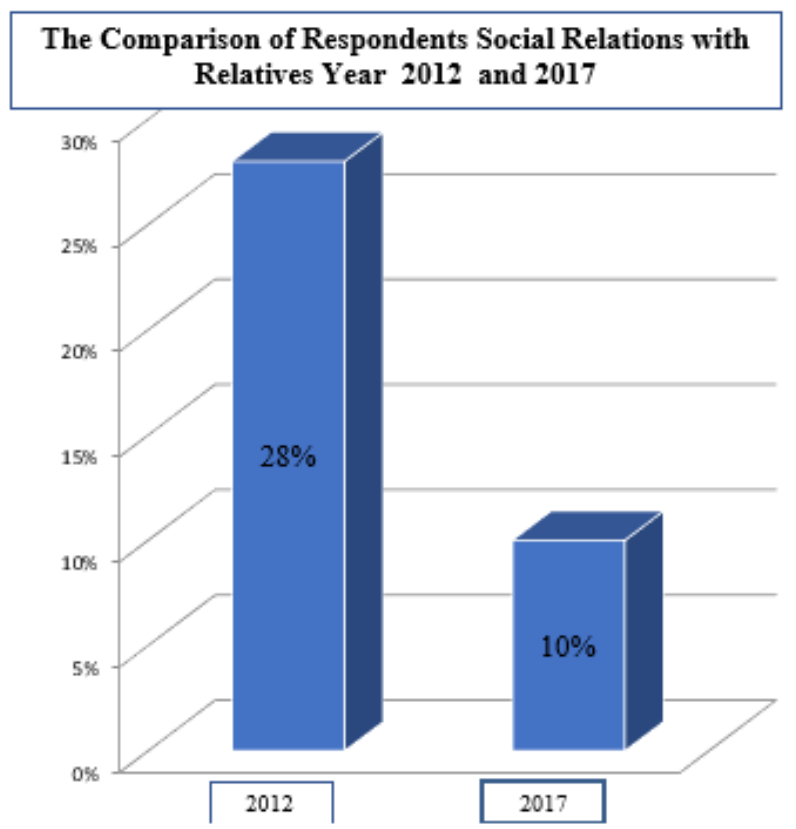

Graph 4. Comparison of Respondent's Social Relations with family of 2012 \& 2017

Viewed from the relationships with neighbors especially in asking for help and the loans also decreased about $15 \%$ from 2012 to 2017 . In picture 5 below; 
The Comparison of Respondence Social Relations with Friends or Neighbors Year 2012 \& 2017

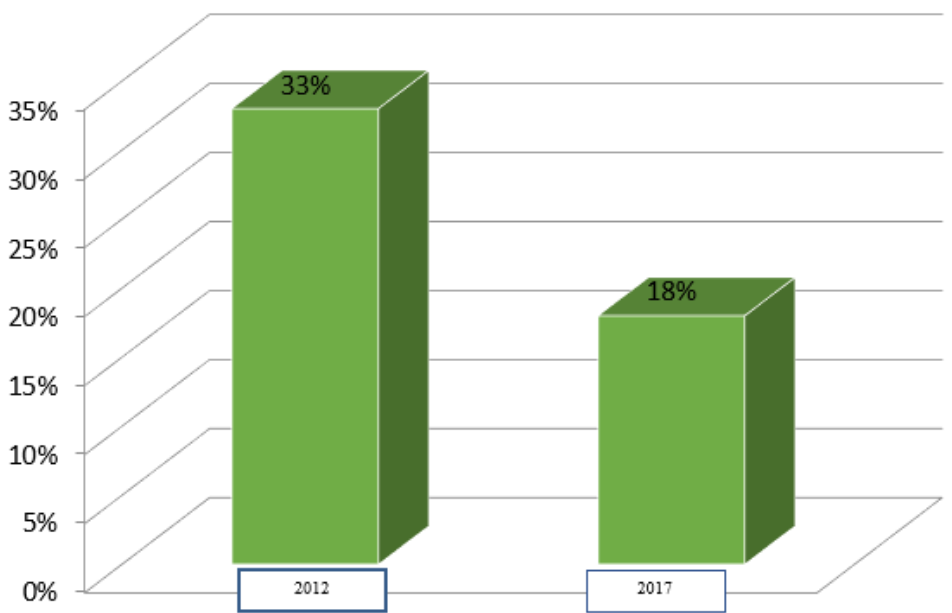

Graph 5. Comparison of Respondent's Social Relations With Friends or Neighbor Year 2012 \& 2017

\subsection{Economic Dependency}

The fourth form of social capital dynamics is the dependency between individuals or groups, especially in the economic field. Dependence is the life condition of a person depends on others. Based on field data of globalization and modernization that enter the countryside under the positive impact where the dependence of society on the economic side has decreased in the last 5 years that is $11 \%$. In Figure 6 below can be seen,

\section{The Change Of Economic Dependency Rate Year 2012 \&2017}

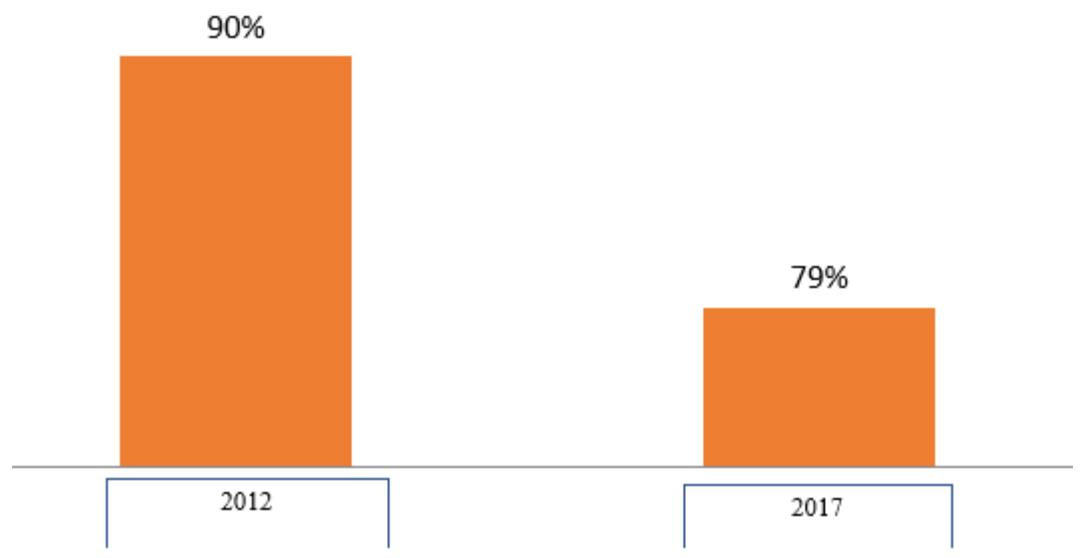

The decline in the economic dependence of the poor towards neighbours or neighbours, is a positive outcome of modernization and globalization. This position makes the 
community more persistent and rational in improving economic life. Dependence has been caused by the poverty that impose them, the poverty makes the dependence on the poor economy high on the help of others, especially family, friends and neighbours.

\section{Conclusion}

Conflict in the Raya market Padang City post-earthquake in 2009 is one form of conflict asymmetrical. The warring parties basically structurally and power flaw. The government as parties who have power or power fight with traders who in structurally have no power to attempt conflict resolution of the role city Padang council is important in effort to resolution. The council has relation by the community as its constituents or the council is the representation of the community. And that city council has representatives function of council of the society sued to do their job as an institution control and escort the government. Here the supervisory function of DPRD to municipal the policy in line legislation and regulations. With the implementation of this parliament interests market traders of Raya market victims 2009 well accommodated.

\section{Reference}

1. Soetomo. Pemberdayaan Masyarakat. Yogyakarta: Pustaka Pelajar, (2011)

2. Dwipayana, dkk. Membangun Good Governance di Desa. Yogyakarta : IRE Pres, (2003)

3. Putnam, R. Making democracy work: civic traditions in modern Italy. Princeton, NJ, (1993)

4. Areekul, Chananporn dkk. Modal Development For Strengthening Social Capital For Being A Sustainable Lifelong Learning Society. Journal Procedia Social and Behavioral Sciences 191, ( 2015 ) $1613-1617$.

5. Hasbullah, Jousairi. Social Kapital (Menuju Keunggulan Budaya manusia Indonesia). Jakarta: MR-United Press.

6. Soemardjan, Selo. Perubahan Sosial di Yogyakarta. Yogyakarta: UGM Press, (1981)

7. Haferkamp, Hans \& Neil J. Smelser. Social Change and Modernity. Los Angeles Oxford: University Of California Press, (1992) 